\title{
Value Chain Analysis At Bank Sampah Bersinar In Bandung Regency As A Competitive Advantage Strategy
}

\author{
Galang Aji Pangestu ${ }^{1}$, Retno Setyorini ${ }^{2}$ \\ Business Administration, Telkom University, Indonesia \\ ${ }^{1}$ E-mail address galangajipngst97@gmail.com; 2 E-mail address \\ retnosrini@telkomuniversity.ac.id
}

\begin{abstract}
This study aimed to determine and analyze the value chain of waste management at Bank Sampah Bersinar in Bandung. The subjects in this study were the actors of the waste management value chain. In this study, there were three informants selected by purposive sampling and snow ball sampling methods. This study was conducted by using qualitative methods with the analysis method including value chains, SWOT analysis, value added and competitive advantage strategies. Based on the results of the discussion and analysis conducted in this study, it was found that in general Bank Sampah Bersinar only conducts basic value chain activities of waste management (input-process-output) without giving a higher value than the waste results obtained. For this reason, additional activities are needed to add more value to the treated waste. Furthermore, the results of the SWOT analysis revealed three main problems faced by Bank Sampah Bersniar namely distance or location, purchase price and public knowledge. The analyzed value chain improvement strategy is proved by the illustrations made, which indicates that it can increase waste value added from 6.86 percent to 74.36 percent.
\end{abstract}

Keywords: value chain, SWOT analysis, value added, and competitive advantage.

This is an open access article under the CC-BY-NC license.

\section{INTRODUCTION}

Until the present moment, waste is still considered as any product or material which is useless and has no value. Waste is a classical problem of modernizing societies, particularly for big cities in Indonesia. The level of solid waste production continues to increase along with the increase in population and changes in the consumptive pattern of the community which causes an increase in the number, types and diversity of existing waste characteristics. According to the Ministry of Environment and Forestry (KLHK), an average person in Indonesia produces 0.7 kilogram of waste per day. Indonesian generated 175,000 tons of waste per day, amounting to 64 million tons per year (Baqiroh, 2019). The data explained that the high level of waste accumulation is caused by the low understanding of the community with regard to appropriate waste management systems.

Application of the 3R pattern (reduce, reuse, recycle) can be the simplest solution that can be done by the community. However, due to the lack of awareness and understanding, people are 
reluctant to do this and choose to dispose of it at the nearest waste disposal site (TPS) for handling by the government. If this problem continues to be left behind, the problem of accumulation of waste in the community will never be overcome.

In an effort overcome the waste problem, the government has tried to establish and maximize the function of the existing waste banks. The waste bank is often associated with the creation of new models to manage household waste by carrying out the waste management business activities by adopting the banking system. The government efforts to overcome the problem of waste through waste banks are contained in Indonesian Government Regulation No. 81 of 2012 on Domestic Waste Management and similar waste. This was enacted to regulate the local policies that would essentially enforce Indonesian, who are not yet used to separating waste, into sorting their waste and foster public awareness in managing waste properly. For this reason, development, utilization and distribution of waste banks must be immediately optimized. The Ministry of Environment and Forestry (KLHK) stated that there were 5,244 waste banks in 34 provinces and 219 cities in Indonesia in 2017 (Velarosdela, 2018).

Unfortunately, Bank Sampah Bersinar has not been able to fully attract the attention of the public to participate in business processes until lately. In fact, if the community, the government, related institutions and the waste banks are able to synergize well, it will certainly become a great force to overcome the problem of waste accumulation in Indonesia and provide benefits for the various stakeholders involved. With that in mind, the authors take a comprehensive analysis on the value chain system at Bank Sampah Bersinar business activities by using SWOT analysis to determine the value added that exists as one indicator to produce a competitive advantage strategy.

\section{LITERATURE REVIEW}

\subsection{Operations Management}

The term management is defined as management which includes planning, organizing, directing, coordinating and controlling. Furthermore, the term operation in operations management is defined as a unit of all activities related to the production of goods and services. Thus, according to the expert, operations management is an activity to regulate and coordinate the use of resources included in human resources, tool resources and funding resources, as well as materials that effectively and efficiently create and add utility to goods and services (Assauri, 2008). Production is also referred to as the operation term which is one of the main functions of the business besides the function of marketing, finance and human resources. This function is related to organizational resources in terms of changing raw materials into finished goods or services that are ready to be marketed.

\subsection{Supply Chain Management (SCM)}

Defined according to (Heizer, et al., 2005) that supply chain management is a series of activities of processing raw materials into goods in processing semi-finished goods and finished goods which are then sent to the consumers through a distribution system. These various activities include traditional purchasing functions and other important activities related to suppliers and distributors. In other words, supply chain management is considered as a strategic approach in terms of demand, operations, purchasing and logistics process management. 


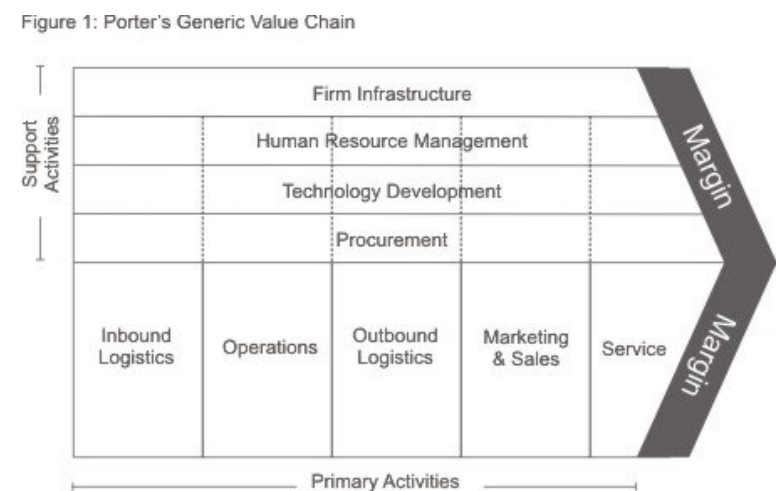

Fig. 1 Porter's Generic Value Chain

(Source: Porter 1985)

Value chain is the disaggregating of a firm into its strategically relevant activities for the purpose of understanding the behavior of costs as well as the existing and potential sources of differentiation (Porter, 1994). To classify activities in a value chain analysis, the conditions that must be met are as follows: 1) Having different economic characteristics, 2) Having a potentially large impact on differentiation, and 3) Taking a significant proportion of costs or tending to be increasingly big.

Before conducting an analysis of the value chain, it is important to know clearly the definition of the value chain itself proposed by several experts. According to (Assuari, 2011), a value chain is a highlevel model of how businesses receive raw materials as input, add value to the raw materials through various processes, and sell finished products to the customers.

\subsection{Value Chain Analysis}

The concept of the value chain explains that the main purpose of the business is to generate profits that are realized through cooperation between related parties. (Porter, 1985) stated that the value chain is the framework provided to explain how an organization can manage and allocate its resources, create differences and effectively manage all the costs required. (Blocher, et al., 2000) revealed that there are three stages in value chain analysis activities: 1) Identifying value chain activities, 2) Identifying cost drivers in each value activity, and 3) Developing competitive advantage.

\subsection{Waste Bank}

A waste bank is established to solve the problem of waste generation that is increasing and has not been able to be resolved properly, and to regulate the local policies for accustoming the community to dispose of waste properly and manage them to be served as a collection of waste which in turn has the economic value, educate the community to get accustomed to sorting and recycling waste appropriately and finally gives understanding and awareness to the community that proper sorted waste equals to highly valuable waste.

\subsection{Value Added}

According to (Mangifera, 2015) value added of a product is defined as the value of the final product minus the cost included in the production of goods and services. Value added is the value generated at the stage assisted by factors of production such as labor, raw materials information, intellectual ability and exchange of relationships in forming the cooperation. Furthermore, the value added itself is the development of value with the input of a commodity. Inputs on a commodity can change shape, time and place (Wibowo, 2014). 
Value added $=$ value of output - contribution of other inputs - price of raw materials

\section{$2.7 \quad$ SWOT Analysis}

SWOT (Strength, Weakness, Opportunity, Threat) analysis is the identification of factors in formulating a company's strategy. According to (Rangkuti, 2008) SWOT analysis is an analytical activity based on logic to maximize the strengths and the opportunities, but at the same time can minimize the weaknesses and the threats. SWOT analysis (Strength, Weakness, Opportunity, Threat) is one form of the company's internal and external environmental analysis instruments at large. This analysis is based on assumptions that explain a strategy that is most effective and will minimize weaknesses and threats. If properly and accurately applied, this simple assumption will have a large impact on the design of a success strategy.

\subsection{Competitive Advantage}

Competitive advantage is defined as a strong union between company excellence and organizational effectiveness in implementing changes in the environment. Moreover, competitive advantage is also an explanation of facts from management which is a process to identify, develop and put a real advantage. Competitive advantage allows a company to produce more effective activity performance compared to its competitors by allowing the productive entity to generate more sales or superior margins.

Efforts to increase the high capability of all sources that produce low costs and increase the value created for customers are considered as the position control of the company's excellence. As for company sources (Barney, 1991) explained that there are three main sources: 1) sources of physical capital, 2) sources of human capital, and 3) sources of organizational capital.

\section{RESEARCH METHODOLOGY}

\subsection{Framework}

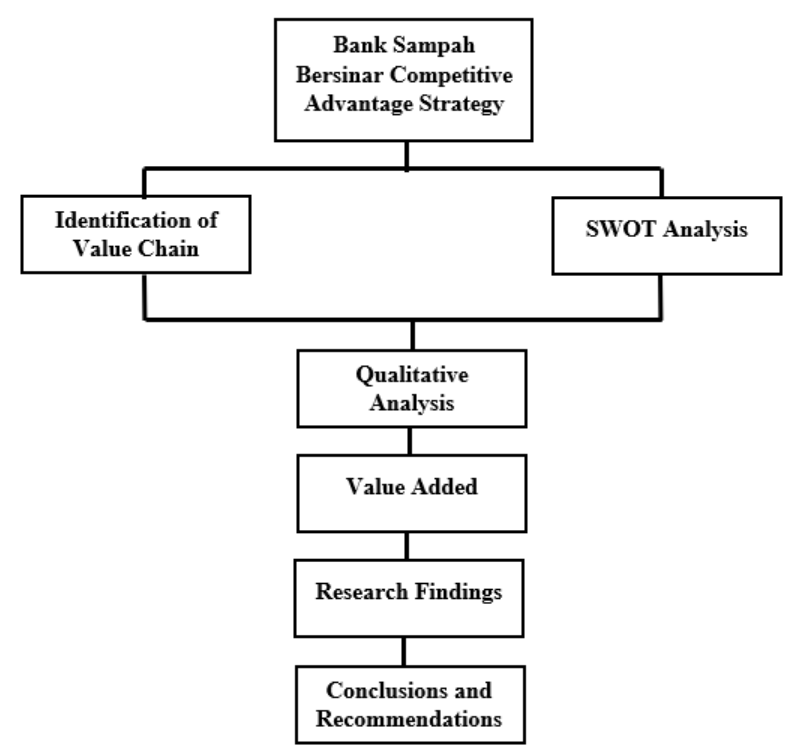

Fig. 1 Research Framework

(Source: Processed by the Authors) 
In this study, the authors observed Bank Sampah Bersinar in Bandung Regency by taking the value chain as the object of this study to improve or optimize the competitive advantage that they have. This study used qualitative analysis as the research model. The framework began by identifying the value chain and analyzing the SWOT (Strength, Weakness, Opportunity, Threat) factors at Bank Sampah Bersinar. Then a qualitative analysis is carried out on the identification of the value chain, and the SWOT analysis will reveal the value added in the business process of Bank Sampah Bersinar. Furthermore, the findings of this study will be used to produce a competitive advantage strategy for Bank Sampah Bersinar, so that the business processes will be better and optimal than before. Next, the final stage is to provide conclusions and suggestions for the parties involved, to get positive results for the strategy of competitive advantage and productivity.

\subsection{Methodology}

This study used qualitative data types that can be categorized into primary data and secondary data. In this study, the primary data were obtained directly by the authors of the selected research object, namely through interviews or direct interviews and field observations with employees or managers of Bank Sampah Bersinar or the most important actors in the value chain flow of waste management activities. Furthermore, the secondary data was obtained through the literature from previous studies and related institutions such as Environmental Agency of Bandung Regency, Central Statistics Agency of Bandung Regency and others.

Purposive sampling and snowball sampling are the sample collection techniques widely used in qualitative study. Purposive sampling is defined as a technique for sampling data sources through a particular consideration, the main goal of this technique is to focus in particular characteristics of a population that are of interest, which will best enable the researchers to answer the research questions. Meanwhile, snowball sampling is defined as a data source sampling technique, where the researchers begin with a small population of known individuals and expand the sample by asking those initial participants to identify others that should participate in the study (Kuncoro, 2013).

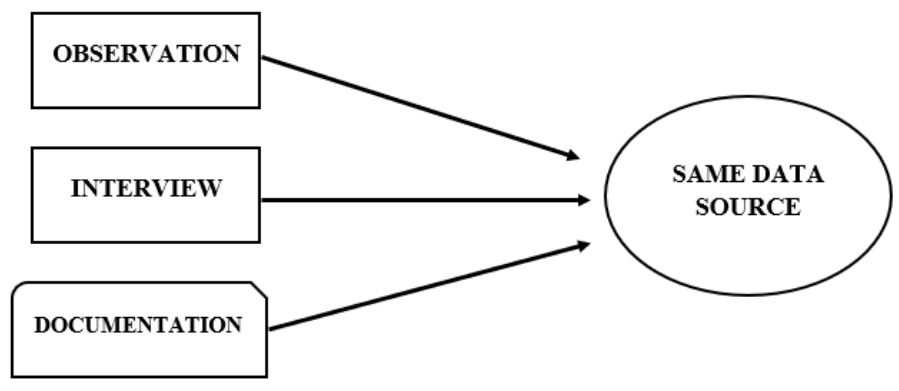

Fig. 3 Triangulasi Method Concept

(Source: Sugiyono 2014)

\section{FINDING AND DISCUSSION}

\subsection{Finding}

\subsubsection{Identification of Actors and Value Chain Scheme at Bank Sampah Bersinar}

The value chain activities of Bank Sampah Bersinar involve several actors, including household customers, employees or managers of waste banks, and industry as final consumers. Each actor in a value chain activity can produce the value added from the waste results obtained. In the business scheme carried out by Bank Sampah Bersinar consists of input, process and output activities. Input activity is the process of receiving or picking up the waste that has been collected by consumers to 
be submitted to the waste bank. Waste that can be accepted is waste with predetermined criteria with different prices for each type of waste. After the waste is received and meets the criteria, then a weighing form will be given to enter the stored data. Furthermore, savings books owned by the consumers will be printed with the latest waste results, so they can be exchanged for available rewards.

Process activity is considered as any activity of waste management that have been carried out by the consumers. Waste collected will be divided into two types, namely waste that meets the criteria and that does not meet the criteria. The type of waste that meets the criteria will immediately enter the cleaning and weighing stages which will then be recorded in the stock book, so that it is ready for sale. Meanwhile, the type of waste that does not meet the criteria, will be sorted out by the waste banks that will be disposed of separately, the next step is cleaning and weighing which will also be recorded on a stock book, so that it is ready for sale.

Finally, the output activity is defined as the final process which is the waste output that is ready for sale. The waste will later be sold and distributed to parties in need such as the Central Waste Bank, individuals, and related industries. This process is also a source of income of Bank Sampah Bersinar to restart its business processes.

\subsubsection{Bank Sampah Bersinar Value Chain: Current State}

The results of the study found that Bank Sampah Bersinar is still trying to improve its value chain until lately. Furthermore, the authors will describe the results of the interviews about the value chain into Primary Activities and Support Activities. Where the Primary Activities consist of inbound logistics, operations, outbound logistics, marketing and sales, and service factors. Meanwhile, the Supporting Activities consist of firm infrastructure, human resource management, technology, and procurement.

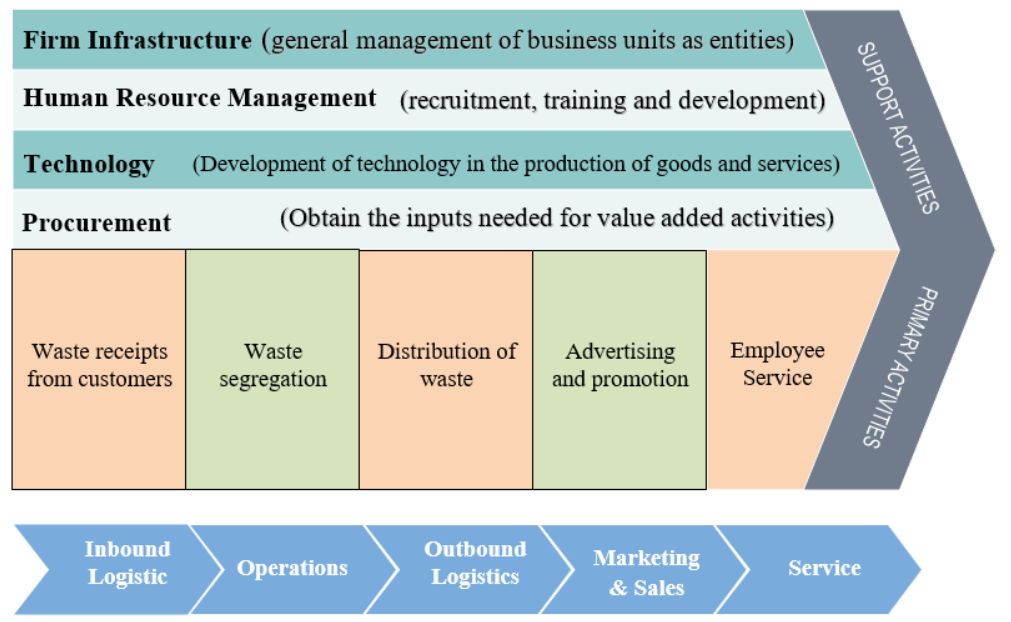

Fig. 4 Value Chain Bank Sampah Bersinar (sumber: Bank Sampah Bersinar, olahan penulis)

\subsubsection{SWOT Analysis}

Table 1. SWOT Analysis of Bank sampah Bersinar

\begin{tabular}{|c|c|c|c|}
\hline Strength & Weakness & Opportunity & Threat \\
\hline
\end{tabular}




\begin{tabular}{|c|c|c|c|}
\hline $\begin{array}{l}\text { 1. Have their own waste } \\
\text { management and several } \\
\text { partners or units spread out } \\
\text { across the community. }\end{array}$ & $\begin{array}{l}\text { 1. There is still a lack of } \\
\text { facilities owned by the } \\
\text { Bank Sampah Bersinar } \\
\text { in terms of waste } \\
\text { management. }\end{array}$ & $\begin{array}{l}\text { 1. Can reduce the amount } \\
\text { of waste that enters the } \\
\text { landfill (Final Waste } \\
\text { Disposal) }\end{array}$ & $\begin{array}{l}\text { 1. There is competition with } \\
\text { trash pickers and collectors in } \\
\text { the purchase price of waste. }\end{array}$ \\
\hline $\begin{array}{l}\text { 2. Work closely with } \\
\text { agencies or related parties } \\
\text { (such as burlap) in } \\
\text { application management as } \\
\text { supporting media. }\end{array}$ & $\begin{array}{l}\text { 2. Too dependent on the } \\
\text { activeness of the } \\
\text { management and } \\
\text { customers in waste } \\
\text { management. }\end{array}$ & $\begin{array}{l}\text { 2. Has the potential to } \\
\text { increase regional income. }\end{array}$ & $\begin{array}{l}\text { 2. Low understanding of the } \\
\text { community that makes Bank } \\
\text { Sampah Bersinar difficult to } \\
\text { develop. }\end{array}$ \\
\hline $\begin{array}{l}\text { 3. Provide additional } \\
\text { income for the community } \\
\text { involved. }\end{array}$ & $\begin{array}{l}\text { 3. Limited place of } \\
\text { business and scope of } \\
\text { business that is still } \\
\text { small. }\end{array}$ & $\begin{array}{l}\text { 3. Able to overcome and } \\
\text { reduce waste } \\
\text { management costs. }\end{array}$ & $\begin{array}{l}\text { 3. Community ignorance } \\
\text { regarding information to } \\
\text { become customers of Bank } \\
\text { Sampah Bersinar. }\end{array}$ \\
\hline $\begin{array}{l}\text { 4. Change waste into more } \\
\text { valuable goods. }\end{array}$ & $\begin{array}{l}\text { 4. Do not have a good } \\
\text { price management so it } \\
\text { is difficult to set prices } \\
\text { (waste prices are still } \\
\text { volatile). }\end{array}$ & \begin{tabular}{|lrrr} 
4. Cooperate & with other \\
parties & to & develop \\
business & such & as \\
government & or & private \\
institutions. & & &
\end{tabular} & $\begin{array}{l}\text { 4. The organizational } \\
\text { structure and job } \\
\text { responsibilities are not } \\
\text { optimal. }\end{array}$ \\
\hline
\end{tabular}

(Source: Bank Sampah Bersinar, processed by the authors)

\subsubsection{Result of Problem Identification of Bank Sampah Bersinar}

After conducting interviews and observations with several employees of Bank Sampah Bersinar, it was found several problems that hamper the business developments towards process oriented and the business power to defeat the competitors. From the SWOT analysis (Strength, Weakness, Opportunity, Threat), the main factors of the problems are the distance or location, purchase price, and public knowledge.

This distance or location problem comes from various complaints from customers who feel that the access to deposit their waste to Bank Sampah Bersinar is too far to go, so it takes a lot of time and money. The strategy that should have been done was to make it look as if Bank Sampah Bersinar was on every side of the community. Actually this has been done by forming partners or units in each community group to facilitate customers in depositing their waste to Bank Sampah Bersinar. However, the quantity of partners or units is still too small to reach the wider community. So it is better if the formation of partners or units must be increased, in line with the development of customers each time. Furthermore, creating a routine pickup system for customers who have limited access also need to be done, so that all levels of society will be reached by the existence of a good scheduling system from Bank Sampah Bersinar.

The second problem is about the purchase price which is considered too low. In the previous discussion, the authors have explained the reasons of Bank Sampah Bersinar that is unable to provide a high purchase price. That is due to the industry or the final consumer that also make a purchase towards the finished waste that has been processed by Bank Sampah Bersinar at a low price. For this reason, the strategy that should be taken by Bank Sampah Bersinar to overcome these problems is 
by adding value to the waste that has been obtained from the customers. One way that can be done is to manage waste from the customer further into product creation that has a higher purchase value. Therefore, Bank Sampah Bersinar will get higher income, so that the purchase price that will be given to the customers will also be higher.

The last problem is the lack of public knowledge about the existence and function of waste banks in general. This problem is considered important, because if fewer people know the importance of a waste bank, there will be less business activity carried out by Bank Sampah Bersinar. For this reason, the strategy that should have been adopted by the Bank Sampah Bersinar to overcome these problems is to conduct more socialization and direction for all levels of society. Another way that can be done to increase public knowledge about Bank Sampah Bersinar is by collaborating with relevant agencies such as the Environmental Agency of Bandung Regency, schools or nearby universities, to industries that are considered to have large quantities of waste every day. With good synergy between these parties, it will later strengthen the function and role of Bank Sampah Bersinar and provide benefits for all relevant stakeholders.

4.2 Discussion

4.2.1 Value Chain Development

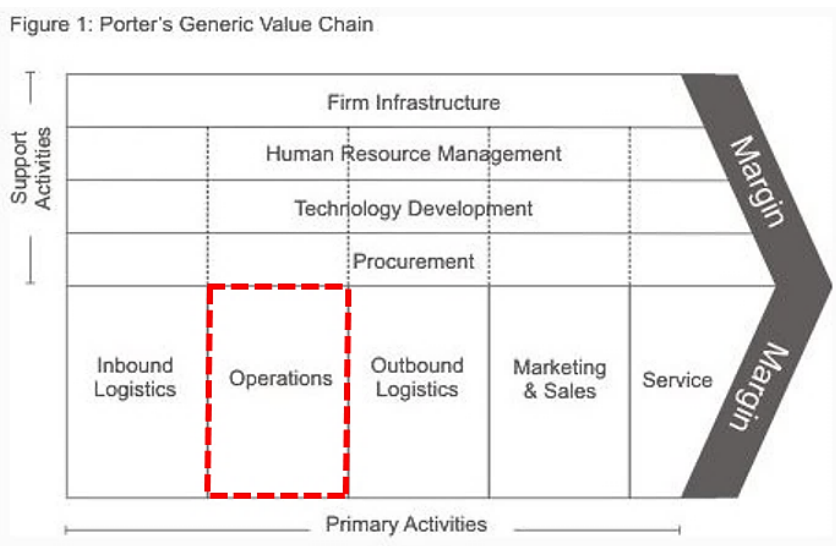

Fig. 5 Porter's Generic Value Chain

(Source: Porter 1985, processed by the authors)

In general, the biggest problem of Bank Sampah Bersinar occurs in the operations section. This factor is quite crucial considering that there is a core business process of the waste banks in the operations section, which is sorting and cleaning up the waste for further processing. If mititigation is not done properly, it will certainly inhibit Bank Sampah Bersinar to have a competitive advantage with other competitors.

\subsubsection{Generic Competitive Strategies At Bank Sampah Bersinar}

According to Michael Porter, Generic Competitive Strategies can be interpreted as an approach to corporate strategy in an effort to win competition with similar industries. Based on the primary data that the authors have obtained, it can be concluded that Bank Sampah Bersinar is in the position or quadrant differentiation on the chosen generic strategy. This is due to Bank Sampah Bersinar has several advantages in the variety of programs that are not owned by waste banks or other competitors in similar industries. Variations in the program, such as payment systems to diverse customers. If other competitors can only pay the results of waste to customers with cash, Bank Sampah Bersinar has various options such as savings at BNI Bank, savings at Pegadaian, savings on food or daily necessities and so on. With a variety of payment options, it is able to influence the choice of the 
customers to make Bank Sampah Bersinar superior in competing. In addition, there are also socialization programs for the customers and prospective customers to get to know the function of the waste bank widely, this also becomes a differentiating point with other competitors in similar industries. An overview of the strategies used by Bank Sampah Bersinar in generic competitive strategies can be seen in the following figure:

Competitive Advantage

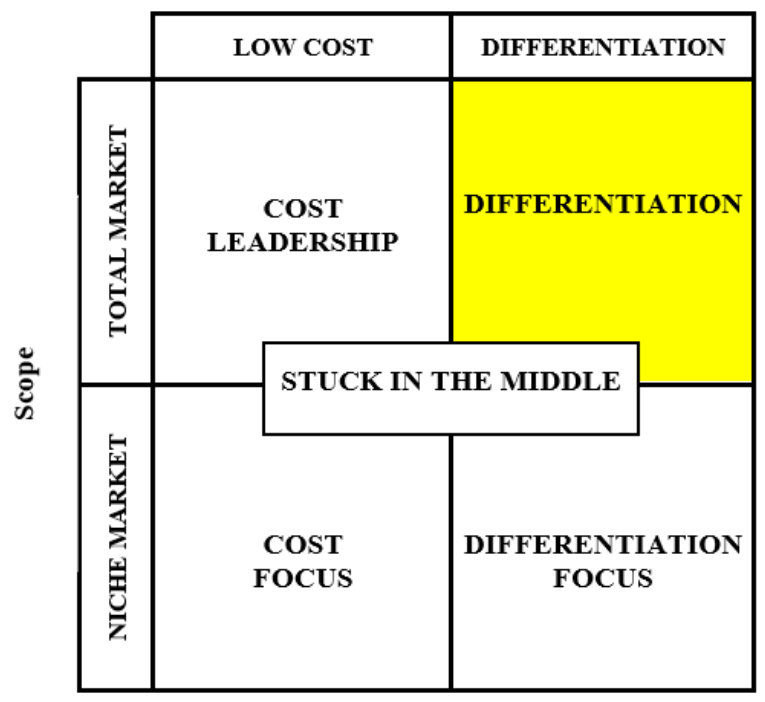

Fig. 6 Bank Sampah Bersinar Generic Strategy

(Source: Porter 1985, processed by the authors)

strategy is considered effective for Bank Sampah Bersinar to encourage companies to be able to obtain a uniqueness that is different from others related industries. This differentiation can enable a company to attract the interests of its potential customers. The differentiation strategy is usually used to target potential customers which are relatively unrelated to the price in the decision making process. It is important that every company develops and identifies parts of a value chain based on a good analysis of its competitive advantage. In this study, Value Chain Analysis has three stages to achieve a competitive advantage strategy, namely:

\section{a. Improvement of Value Chain Activities}

Bank Sampah Bersinar can improve the value chain activities such as design, service and manufacturing processes in its business activities. Because at the present moment, Bank Sampah Bersinar only processes waste sorting and cleaning without further processing in order to provide value added to the waste to be resold. Identification and development of value chains are not the same as each other depending on the type of industry. The basic value chain available at Bank Sampah Bersinar can now be seen in the following figure:

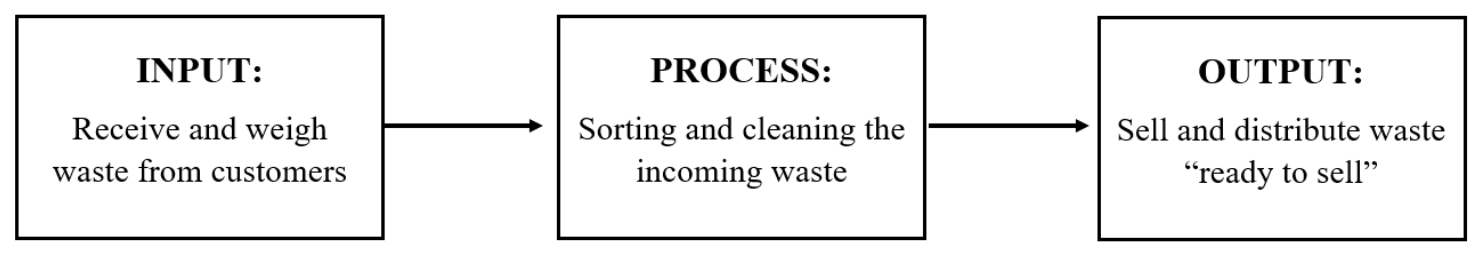

Fig. 7 Basic Value Chain of Bank Sampah Bersinar 
(Source: Bank Sampah Bersinar, processed by the authors)

After further identification, the authors understand that the basic value chain at Bank Sampah Bersinar needs to be amended or optimized by providing additional activities to add value to the waste that has been obtained. With these improvements, it is hoped that later, it will further maximize the function and role of Bank Sampah Bersinar to be better prepared in creating stronger competitive advantages. The basic value chain changes to optimize Bank Sampah Bersinar can be seen in the following figure:

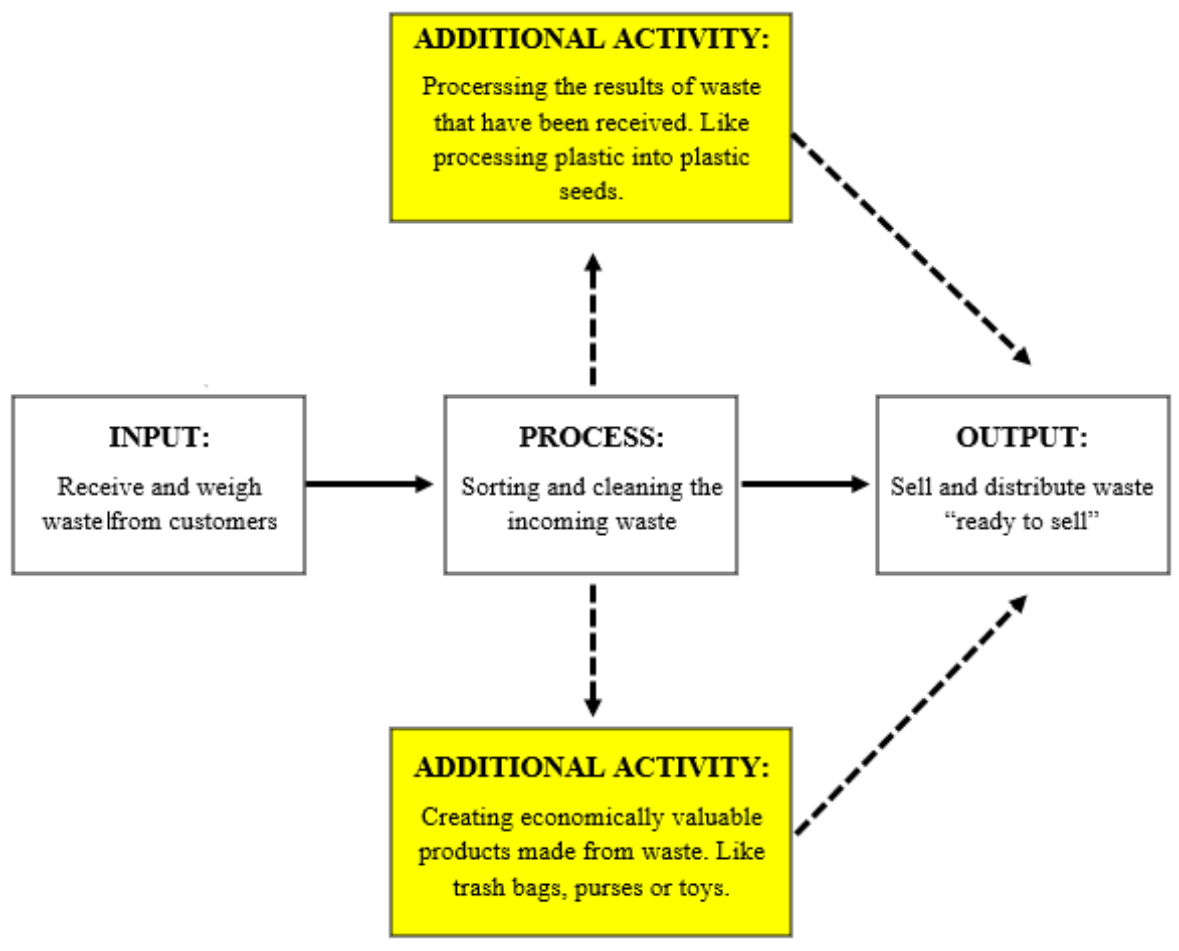

Fig. 7 Basic Value Chain Optimization of Bank Sampah Bersinar (sumber: Bank Sampah Bersinar, olahan penulis)

The activity of optimizing the basic value chain at Bank Sampah Bersinar can be conducted by providing additional activities to change the function of the waste that is found to be more valuable. The first additional activity is to process the waste that has been found to be more valuable.

\section{b. Value Added Analysis of Bank Sampah Bersinar}

The value added of the waste collected by the customer or household will be determined by Bank Sampah Bersinar as the purchase price based on the quantity and type of waste that has been set. Every activity in the value chain of waste management processed for sale has the value added to the results of the waste that is ready for sale, while the cost of waste management consists of waste purchasing from customers, waste management labor and company supporting costs. The detail of the costs required during the management process of waste that is ready to sell to the industry is presented on the following table: 
Table 2. Value Added of Waste Management of Bank Sampah Bersinar

\begin{tabular}{|c|c|c|c|c|c|}
\hline No. & Cost Type & $\begin{array}{c}\text { Lowest } \\
\text { Cost }\end{array}$ & $\begin{array}{c}\text { Average } \\
\text { Cost }\end{array}$ & $\begin{array}{c}\text { Highest } \\
\text { Cost }\end{array}$ & $\begin{array}{c}\text { Value } \\
\text { Added } \\
(\%)\end{array}$ \\
\hline \multicolumn{6}{|c|}{$\begin{array}{l}\text { Waste Management Costs (waste purchasing from customers, waste management labor } \\
\qquad \text { and company supporting costs) }\end{array}$} \\
\hline 1. & $\begin{array}{l}\text { Waste Purchasing from Customers (e.g. mineral } \\
\text { water packaging waste) }\end{array}$ & 5.040 & 5.320 & 5.600 & \\
\hline 2. & Waste Management Labor (wages per kg) & 500 & 600 & 700 & \\
\hline 3. & $\begin{array}{l}\text { Supporting Materials (plastic/carton packing, } \\
\text { etc.) }\end{array}$ & 500 & 600 & 700 & \\
\hline \multicolumn{5}{|c|}{$\begin{array}{l}\text { The average costs of waste management } \\
\text { (e.g. mineral water packaging waste } / \mathrm{kg} \text { ) }\end{array}$} & 6.520 \\
\hline \multicolumn{5}{|c|}{$\begin{array}{l}\text { The purchase price of waste to the industry } \\
\text { (e.g. mineral water packaging waste } / \mathrm{kg} \text { ) }\end{array}$} & 7.000 \\
\hline \multicolumn{5}{|r|}{ Profits } & 480 \\
\hline \multicolumn{5}{|c|}{ Value Added } & $6,86 \%$ \\
\hline
\end{tabular}

(source: Bank Sampah Bersinar, processed by the authors)

Referring to the results of interviews conducted by the authors, to produce ready-to-sell waste (assumed to be mineral water packaging waste per $\mathrm{kg}$ ), an average costs of waste management in the amount of Rp 6,520 is required. Bank Sampah Bersinar will usually offer an industry purchase price of no more than Rp 500 per kilogram. So the purchase price of waste to the industry (assumed to be mineral water packaging waste per $\mathrm{kg}$ ) is $\mathrm{Rp} .7,000$, the profits that will be obtained by Bank Sampah Bersinar for each kilogram of waste transaction is approximately Rp. 480 with the value added only by 6.86 percent. The amount of value added is obtained from profits divided by the purchase price of waste then multiplied by 100 percent.

To provide a comparison of the value added of waste management, in the following illustration, the authors will assume the mineral water packaging waste per kilogram into products creations in the form of flower vase, pencil case and so forth. One kilogram of mineral water packaging waste is assumed to consist of 30 to 50 plastic bottles or cups. The detail of the costs needed during the process of waste management into product creations is presented on the following table: 
Table 3. Improvement of the Value Added of Waste Management at Bank Sampah Bersinar

\begin{tabular}{|c|c|c|c|c|c|}
\hline No. & Cost Type & Lowest Cost & $\begin{array}{l}\text { Average } \\
\text { Cost }\end{array}$ & Highest Cost & $\begin{array}{c}\text { Value } \\
\text { Added (\%) }\end{array}$ \\
\hline \multicolumn{6}{|c|}{$\begin{array}{l}\text { Waste Management Costs (waste purchasing from customers, waste management labor, } \\
\text { product creation labor, equipment and company supporting costs) }\end{array}$} \\
\hline 1. & $\begin{array}{l}\text { Waste Purchasing from } \\
\text { Customers (e.g. mineral water } \\
\text { packaging waste) }\end{array}$ & 5.040 & 5.320 & 5.600 & \\
\hline 2. & $\begin{array}{l}\text { Waste Management Labor } \\
\text { (wages per kg) }\end{array}$ & 500 & 600 & 700 & \\
\hline 3. & $\begin{array}{l}\text { Product Creation } \text { Labor } \\
\text { (wages per } \mathrm{kg} \text { ) }\end{array}$ & 20.000 & 22.500 & 25.000 & \\
\hline 4. & $\begin{array}{l}\text { Equipment (glue, brushes, } \\
\text { scissors, etc.) }\end{array}$ & 30.000 & 32.500 & 35.000 & \\
\hline \multirow[t]{6}{*}{5.} & $\begin{array}{l}\text { Supporting Materials } \\
\text { (plastic/carton packing, etc.) }\end{array}$ & 15.000 & 16.000 & 17.000 & \\
\hline & The avera & $\begin{array}{r}\text { (e.g. } 1 \\
\text { (est of waste } 1\end{array}$ & $\begin{array}{l}\text { ggement intc } \\
\text { ral water pa }\end{array}$ & $\begin{array}{l}\text { duct creations } \\
\text { ging waste } / \mathrm{kg} \text { ) }\end{array}$ & 76.920 \\
\hline & (assumed to be one kilogram of & $\begin{array}{l}\text { The average cost } \\
\text { vaste produces a }\end{array}$ & $\begin{array}{l}\text { vaste manag } \\
\text { imum of } 30\end{array}$ & $\begin{array}{l}\text { nt per product } \\
\text { tles or glasses) }\end{array}$ & 2.564 \\
\hline & & The purchase pr & $\begin{array}{l}\text { f waste to tl } \\
\text { (price of per }\end{array}$ & $\begin{array}{l}\text { nal consumers } \\
\text { duct creation) }\end{array}$ & 10.000 \\
\hline & & & & Profits & 7.436 \\
\hline & & & & Value Added & $74,36 \%$ \\
\hline
\end{tabular}

(source: Bank Sampah Bersinar, processed by the authors)

After being given an illustration of additional business activities to further manage the waste that has been obtained from customers, it was obtained a higher value added result. Based on table 4.8 obtained from interviews conducted by the authors and formed an illustration, then from one kilogram of plastic waste (assumed to be one kilogram of mineral water packaging waste consisting of 30 to 50 plastic bottles or cups), the average cost of processing product creation is Rp. 76,920. The total cost of product creation in kilograms is divided by 30 products (it is assumed that one kilogram of waste produces a minimum of 30 bottles or plastic cups), so that the amount of processing costs per product creation is $\mathrm{Rp} 2,564$. So the purchase price of product creations (flower vases, pencil cases, and others) to the consumers is approximately $\mathrm{Rp} 10,000$, then the profits to be obtained by Bank Sampah Bersinar for each product creation are approximately Rp. 7,436, with the value added which is much higher than before, namely 74.36 percent. The value added is obtained from the profit divided by the purchase price of the product creation, then multiplied by 100 percent. 
Competitive advantage can be created if Bank Sampah Bersinar knows exactly what strengths and opportunities they can develop, and what weaknesses and threats they can overcome. When the concept can be implemented, the activities of Bank Sampah Bersinar will be even better. By the results of this conductrd study, it can be explained that the provision of additional activities in the value chain is able to produce the value added which is much greater in the business of Bank Sampah Bersinar. So that, this helps to explain that the competitive advantage strategy will be more optimal.

\section{CONCLUSION AND FURTHER RESEARCH}

\subsection{Conclusion}

Based on the results and discussion of this study that the authors have described before, the conclusions can be drawn as follow:

a. The main activities of the value chain at Bank Sampah Bersinar are:

1) Inbound logistics, namely the receipt of waste from customers.

2) Operations, namely the process of sorting and managing into waste that is ready to sell.

3) Outbound logistics, namely the process of receiving orders and distributing waste ready to sell.

4) Marketing and sales, namely the advertising and promotion process to introduce the Bank Sampah Bersinar.

5) Service, namely the process of maintaining the value of a product or service to customers.

b. Value chain supporting activities at Bank Sampah Bersinar, namely:

1) Procurement, namely the process of purchasing the inputs needed in business activities.

2) Technology development, namely the process to improve business activities carried out.

3) Human resource management, namely the process that involves the recruitment, training, development and compensation of each employee.

4) Infrastructure Firm, namely a general management process that functions to support the performance of the entire value chain.

c. From the SWOT analysis (strength, weakness, opportunity, threat) that has been done, the results of the problems experienced by Bank Sampah Bersinar are: distance or location, purchase price and public knowledge.

d. The development of the value chain carried out by the authors to optimize the activities of Bank Sampah Bersinar is to improve the value chain activities and value added analysis.

e. The improvement of value chain activities is carried out by providing additional activities in business processes from the previous pattern, namely inputs, processes and outputs. This is done to provide the value added that is greater than the waste obtained.

f. Value added analysis is done by illustrating and comparing Model I with the old pattern of activities and Model II with the pattern of activities that have been changed. Then obtained value added results in Model I of 6.86 percent and Model II of 74.36 percent. 
g. This study can explain and be a reference that the provision of additional activities in the value chain is able to produce the value added that is much greater in the business of Bank Sampah Bersinar.

\subsection{Suggestions}

From the results of study conducted by the authors related to the analysis of the value chain of waste management at Bank Sampah Bersinar in Bandung Regency, suggestions can be given as follows:

a. Customers or the public are expected to be able to increase participation in existing activities at Bank Sampah Bersinar, and to implement better discipline in terms of waste sorting in order to facilitate business processes.

b. The government, agency or related parties are expected to be able to provide support in the form of socialization, training and capital for the principal actors in the value chain of Bank Sampah Bersinar.

c. Further studies are expected to be able to further observe the strengths, weaknesses, opportunities and threats that exist as well as the calculation of value added in more detail as the development of products and services that can improve the performance of Bank Sampah Bersinar.

\section{REFERENCES}

Assuari, S., 2011. Strategic Management, Sustainable Competitive Advantage. Jakarta: s.n.

Bandivadekar, A. et al., 2008. [Online] Available at: http://web.mit.edu/sloan-autolab/research/beforeh2/otr2035/On\%20the\%20Road\%20in\%202035_MIT_July\%202008.pd $\mathrm{f}$

Baqiroh, N. F. A. B., 2019. Timbulan Sampah Nasional Capai 64 juta ton per Tahun. [Online] Available at: https://ekonomi.bisnis.com/read/20190221/99/891611/timbulan-sampahnasional-capai-64-juta-ton-per-tahun

Barney, J. B., 1991. Firm resources and sustained competitive advantage. Journal of Management, pp. 99-120.

Blocher, Chen \& Lin, 2000. Cost Management a Strategic Emphasis. Jakarta: Salemba Empat.

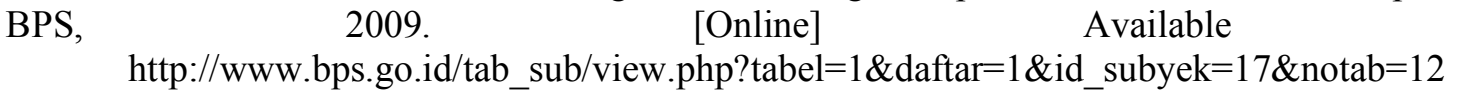

at:

Heizer, Render, J. d. \& Barry, 2005. Operations Management Edisi Ketujuh. Jakart: Salemba Empat.

Kuncoro, M., 2013. Metode Riset untuk Bisnis dan Ekonomi Edisi 4. Jakarta: Erlangga.

Mangifera, L., 2015. Analisis Rantai Nilai (Value Chain) Pada Produk Batik Tulis di Surakarta. Benefit Jurnal Manjemen dan Bisnis, pp. 24-33.

Porter, M. E., 1985. The Competitive Advantage: Creating and Sustaining Superior Performance. New York: Free Press.

Porter, M. E., 1994. Keunggulan Bersaing (Binarupa Aksara, Penerjemah). Jakarta: Binarupa Aksara.

Rangkuti, F., 2008. The Power Of Brands. Jakarta: Gramedia.

Velarosdela, R. N., 2018. Belajar dari Bank Sampah dan Pengolahan Sampah Beromzet Rp 4,5 Miliar. [Online]

Available at: https://megapolitan.kompas.com/read/2018/12/03/13095821/belajar-dari-banksampah-dan-pengolahan-sampah-beromzet-rp-45-miliar

Wibowo, A. P., 2014. Analisis Rantai Nilai (Value Chain) Komoditas Ikan Bandeng di Kecamatan Juwana Kabupaten Pati. Skripsi FEB Universitas Diponegoro. 